Reka Buana : Jurnal Ilmiah Teknik Sipil dan Teknik Kimia, 4 (1), 2019, page 57-62

Tersedia online di https://jurnal.unitri.ac.id/index.php/rekabuana

ISSN 2503-2682 (Online)

ISSN 2503-3654 (Cetak)

\title{
Distribusi Weibull Kecepatan Angin Wilayah Kecamatan Pangarengan Kabupaten Sampang Madura
}

\author{
Arin Wildani ${ }^{1}$, Septiana Kurniasari ${ }^{2}$ \\ ${ }^{1}$ Pendidikan Fisika, FKIP, Universitas Islam Madura-Jl.PP.Miftahul Ulum Bettet Pamekasan \\ ${ }^{2}$ D3 Farmasi, Universitas Islam Madura-Jl.PP.Miftahul Ulum Bettet Pamekasan \\ e-mail: arinwildani@gmail.com
}

\begin{abstract}
ABSTRAK
Pada masa yang akan datang ketergantungan Indonesia terhadap ketersediaan energi fosil menjadi masalah baru dalam kelangsungan hidup rakyat Indonesia karena energi fosil merupakan energi yang tidak terbarukan. Untuk mengatasi masalah tersebut maka diperlukan pengalihan ketergantungan energi tidak terbarukan ke energi terbarukan. Salahsatu energi terbarukan yang potensinya cukup besar yaitu energi angin.. Penelitian ini dilakukan untuk mengetahui potensi pembangunan pembangkit listrik tenaga angin di Kecamatan Pangarengan Kabupaten Sampang Madura. Analisa data pada penelitian ini menggunakan distribusi weibull dengan menggunakan data sekunder yang didapatkan dari dari BMKG Kalianget Sumenep. Berdasarkan distribusi weibull didapatkan bahwa parameter $k$ sebesar 2,67dan $c$ sebesar 2,88. Dari nilai $k$ dan $c$ didapatkan bahwa persentase probabilitas energi angin paling banyak pada tahun 2016 yaitu 2,5 m/s sebanyak 45\% sedangkan tahun 2017 sebesar 2,6 m/s dengan probabilitas $70 \%$.
\end{abstract}

Kata kunci: energi angin; kecamatan pangarengan; distribusi weibull

\begin{abstract}
In the future, Indonesia's dependence on fossil energy availability is a new problem in the survival of the Indonesian people because fossil energy is a non-renewable energy. To overcome this problem, it is necessary to shift the dependence of non-renewable energy to renewable energy. One of the most renewable energy potentials is wind energy. This research was conducted to determine the potential for the construction of wind power plants in Pangarengan District, Sampang Madura Regency. Data analysis in this study used a weibull distribution using secondary data obtained from BMKG Kalianget Sumenep. Based on the weibull distribution it was found that the parameters $k$ were 2.67 and $c$ were 2.88. From the values of $k$ and $c$, it was found that the percentage of probability of wind energy was the most in 2016, which was $2.5 \mathrm{~m} / \mathrm{s}$ as much as $45 \%$ while in 2017 it was $2.6 \mathrm{~m} / \mathrm{s}$ with a probability of $70 \%$.
\end{abstract}

Keywords : wind energy; pangarengan district; weibull distribution

Cara Mengutip : Wildani, A., Kurniasari, S. (2019). Distribusi Weibull Kecepatan Angin Wilayah Kecamatan Pangarengan Kabupaten Sampang Madura. Reka Buana : Jurnal Ilmiah Teknik Sipil dan Teknik Kimia, 4 (1), 57 62. http://dx.doi.org/10.33366/rekabuana.v4i1.1135 


\section{PENDAHULUAN}

Energi merupakan kebutuhan pokok yang harus terpenuhi dalam membangun sebuah peradaban masyarakat suatu bangsa. Sebagai kebutuhan pokok maka ketersediaan energi menjadi salah satu faktor penting. Jika suatu bangsa tidak mampu menyediakan energi maka akan berakibat pada lemahnya kemampuan masyarakatnya untuk berkembang. Indonesia merupakan salahsatu negara yang ketersediaan energinya sangat bergantung pada energi fosil atau energi tidak terbarukan dimana energi tersebut suatu saat akan habis atau tidak tersedia lagi. Namun sebagai negara besar, Indonesia sebenarnya merupakan negara yang sumber daya alamnya melimpah termasuk sumber daya alam yang dapat dimanfaatkan sebagai untuk pemenuhan energi tanpa bergantung kepada energi fosil [1].

Salah satu sumber daya alam yang melimpah tersebut adalah energi angin yang merupakan salahsatu energi terbarukan yang dapat dimanfaatkan untuk pemenuhan kebutuhan masyarakat Indonesia. Potensi energi angin ini masih sangat besar dan belum dimanfaatkan secara maksimal [2].

Energi angin merupakan energi terbarukan yang sangat fleksibel, dapat dimanfaatkan di daratan rendah, dataran tinggi ataupun di laut. Indonesia memiliki potensi energi angin yang sekitar 9,3 GW dan total kapasitas yang baru terpasang saat ini sekitar 0,5 MW [3].

Kajian pemanfaatan energi terbarukan seperti energi angin sangat diperlukan sebagai dasar pengembangan energi terbarukan[4]. Dalam pengembangan energi angin sangat diperlukan data potensi angina secara spesifik dari suatu daerah. Salahsatu daerah yang dapat dijadikan pertimbangan dalam pengkajian potensi energi angin yaitu Pulau Madura. Kondisi strategis Pulau Madura memiliki potensi besar untuk dikembangkan pembangkit listik dari energi terbarukan. Namun selama ini belum banyak kajian yang membahas potensi energi angin di Pulau Madura. Oleh karena itu pada penelitian akan dilakukan kajian mengenai potensi energi angin di Pulau Madura. Daerah yang akan menjadi objek penelitian adalah Kecamatan Pangarengan Kabupaten Sampang.

Kecamatan Pangarengan merupakan daerah yang termasuk dalam kawasan pantai selatan Pulau Madura. Penelitian untuk menganalisis potensi energi angin di Kecamatan Pangarengan belum pernah dilakukan sebelumnya. Penelitian ini merupakan penelitian awal sebagai acuan untuk pembangunan pembangkit listrik tenaga bayu di Kecamatan Pangarengan. Pada penelitian ini analisis potensi angin dilakukan dengan menggunakan distribusi weibull karena dipandang sangat representatif untuk menggambar potensi angin.

\section{METODE PENELITIAN}

Pada penelitian variabel penting yang perlu diketahui yaitu kecepatan rata-rata angin. Pada penelitian ini kecepatan rata-rata angin dihitung menggunakan persamaan 1 .

$V_{m}=\left(\frac{1}{n} \sum_{i=1}^{n} V_{i}^{3}\right)^{\frac{1}{3}}$

keterangan :

$V_{m}=$ Kecepatan angin rata-rata $(\mathrm{m} / \mathrm{s})$

$T_{i} \quad=$ lama waktu angin bertiup

$V_{i} \quad=$ kecepatan angin yang terukur $(\mathrm{m} / \mathrm{s})$

$n \quad=$ jumlah data pengukuran

Langkah selanjutnya analisis kecepatan angin menggunakan distribusi weibull $f(v)$ dengan persamaan 2.

$f(v)=\left[\frac{k}{c}\left(\frac{v}{c}\right)^{k-1}\right] e^{-\left(\frac{v}{c}\right)^{k}}$

keterangan :

$k=$ nilai parameter bentuk tanpa dimensi

$v=$ nilai tengah kecepatan angin $(\mathrm{m} / \mathrm{s})$

e $\quad=$ epsilon 
parameter bentuk $k$ (tanpa dimensi) dan parameter skala $c$ merupakan dua parameter yang diperlukan dalam metode distribusi Weibull. Dimana nilai parameter parameter tersebut tergantung pada data kecepatan angin di lapangan [5]. Nilai parameter bentuk $k$ dapat didketahui dengan menggunakan persamaan 3 berikut:

$k=\left(\frac{\sigma}{v}\right)^{-1,086}$

keterangan :

$s=$ nilai standart deviaasi kecepatan angin

$v=$ nilai tengah kecepatan angin $(\mathrm{m} / \mathrm{s})$

Sementara nilai parameter skala $c$ dapat diketahui dengan menggunakan persamaan 4 brikut:

$c=1,12 v$

$$
(1,5<\mathrm{k}<4)
$$

Nilai parameter skala $c$ akan mempengaruhi kurva distribusi weibull, semakin kecil nilai parameter $c$ maka kurva akan bergeser kearah kecepatan angin yang lebih rendah demikian juga sebaliknnya[6].

Tahapan selanjutnya yaitu menentukan besarnya energi yang dihasilkan udara yang memiliki massa (m) dan kecepatan (v) menggunakan persamaan 5 .

$E=\frac{1}{2} m v^{2}$

Dimana:

$E \quad=$ energi kinetik (joule)

$m \quad=$ massa udara $(\mathrm{kg})$

$v \quad=$ kecepatan angin $(\mathrm{m} / \mathrm{s})$

sedangkan volume udara tiap satuan waktu (debit) yang bergerak dengan kecepatan $v$ dan melalui daerah seluas $A$ dapat dihitung menggunakan persamaan 6 .

$V=v A$

Dan $(m)$ massa udara yang bergerak dalam satuan waktu yang memiliki kerapatan (@) dihitung menggunakan persamaan 7 .

$m=\rho \mathrm{V}=\rho \mathrm{vA}$

Dimana :

$$
\begin{aligned}
m & =\text { massa udara }(\mathrm{kg}) \\
V & =\text { volume udara (debit) }
\end{aligned}
$$

$P=$ densitas udara $\left(\varrho=1,225 \mathrm{~kg} / \mathrm{m}^{3}\right)$

$A=$ luas penampang turbin $\left(\mathrm{m}^{2}\right)$

Sehingga didapatkan daya angin adalah

$P a=\frac{1}{2}\left(\rho A v^{3}\right) \mathrm{Cp}$

Sedangkan untuk perhitungan daya kincir (turbin angin) untuk stimulasi pembangkit listrik tenaga angin yang menggunakan mekanisme servo sebagai pengganti energi angin adalah sebagai berikut[7]:

$p a=\frac{p m}{C p}$.

Besar daya tersebut adalah yang dimiliki oleh angin sebelum melewati turbin angin atau sebelum dikonversi. Tidak semua dari daya tersebut dapat dirubah (dikonversi) menjadi energi mekanik oleh turbin. Untuk perhitungan daya kincir (turbin angin) dengan konstanta kincir $(\mathrm{Cp}=0,592)$ adalah sebagai berikut:

$P m=C p \frac{1}{2}\left(\rho A v^{3}\right)$.

Dimana

$\mathrm{Pa}=$ daya angin (watt)

$P m$ = daya turbin angin (watt)

$\varrho=$ densitas udara $\left(\varrho=1,225 \mathrm{~kg} / \mathrm{m}^{3}\right)$

$A=$ luas penampang turbin $\left(\mathrm{m}^{2}\right)$

$v \quad=$ kecepatan udara $(\mathrm{m} / \mathrm{s})$

$C D \quad=$ konstanta turbin angin $(0,592)$

\section{HASIL DAN PEMBAHASAN}

Data yang digunakan pada penelitian didapatkan dari Badan Meteorologi dan Klimatologi (BMKG) Kalianget. Data yang diperoleh berupa temperatur dan tekanan udara serta kecepatan dan arah angin tahun 2016 dan tahun 2017. Data kecepatan angin dihitung setiap jam yang kemudian di hitung kecepatan rata- rata bulanannya seperti terlihat pada gamabar 1. Rata-rata bulanan kecepatan digunakan untuk mengetahui nilai kecepatan angin maksimum dan minimum [8] di wilayah kecamatan Pangarengan selama satu tahun. Gambar 1 memperlihatkan 
bahwa kecepatan angin tertinggi pada tahun 2016 terjadi pada bulan Agustus yaitu 3,5 $\mathrm{m} / \mathrm{s}$ sedangkan apda tahun 2017 kecepatan angin tertinggi terjadi pada bulan Juli yaitu 3,7 $\mathrm{m} / \mathrm{s}$. Pada gambar 1 juga dapat dilihat kemiripan pola kecepatan angin rata rata bulanan antara tahun 2016 dan 2017. Hal tersebut menunjukkan bahwa kecepatan angin daerah Kecamatan Pangarengan relatif stabil selama dua tahun terakhir.
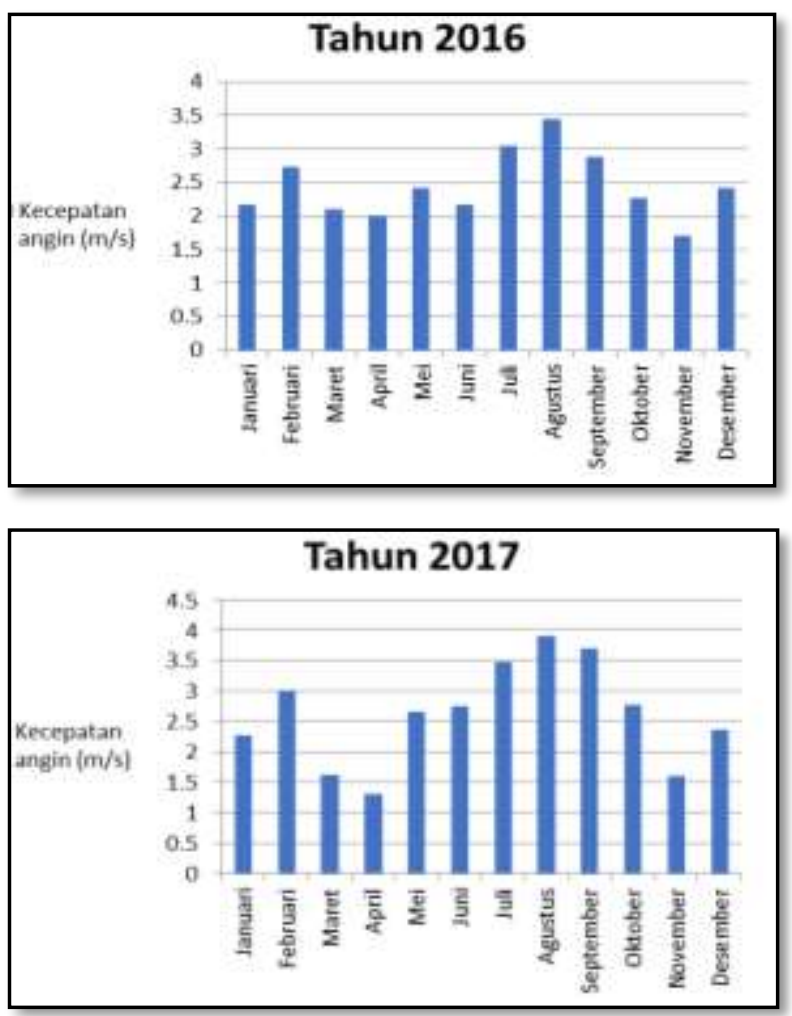

Gambar 1. a) Rata-rata bulanan kecepatan angin tahun 2016 b) Rata-rata bulanan kecepatan angin tahun 2017

Kecenderungan kecepatan angin sepanjang tahun selain dapat dilihat dari rata -rata bulanan kecepatannya juga bisa dilihat dari probabilitas kecepatan angin setiap tahunnya. Probabilitas kecepatan angin pada penelitian ini dihitung menggunakan distribusi weibull. Dalam distribusi Weibull digunakan fungsi distribusi kumulatif $f(v)$ yang menggambarkan persentase kecepatan angin dari waktu kewaktu sama atau lebih rendah dari kecepatan angin sebelumnya.
Pada distribusi weibull dibutuhkan nilai parameter $\mathrm{k}$ dan $\mathrm{c}$ dan pada penelitian ini didapatkan nilai parameter $\mathrm{k}$ dan $\mathrm{c}$ seperti pada tabel 1.

Tabel 1 Nilai parameter $k$ dan $c$ derah kecamatan Pangarengan tahun 2016 -2017

\begin{tabular}{llllll}
\hline No & Tahun & $\begin{array}{l}\text { Vrata2 } \\
(\mathrm{m} / \mathrm{s})\end{array}$ & $\begin{array}{l}\text { Standar } \\
\text { Deviasi }\end{array}$ & $k$ & $c$ \\
\hline 1. & 2016 & 2,44 & 0,49 & 5,67 & 2,88 \\
2. & 2017 & 2,62 & 0,83 & 3,45 & 2,68 \\
\hline
\end{tabular}

Nilai $k$ dan $c$ menunjukan keadaan kecepatan angin di suatu daerah. Nilai parameter $k$ berbanding lurus dengan probabilitas kecepatan angin. Semakin tinggi nilai $k$ maka probabilitas kecepatan angin semakin besar. Sedangkan nilai $c$ menunjukkan keadaan sebaran kecepatan angin. Kecepatan angin memiliki batas minimum yang bisa diaplikasikan untuk dasar pengkajian pembangunan pembangkit listrik tenaga bayu adalah yang memiliki nilai $\mathrm{k}=1,2$. Berdasarkan Tabel 1 dapat diketahui bahwa frekuensi kejadian angin tahun 2016 lebih tinggi dibandingkan tahun 2017 hal tersebut terlihat dari nilai $k$ dan $c$ tahun 2016 lebih tinggi dari tahun 2017.
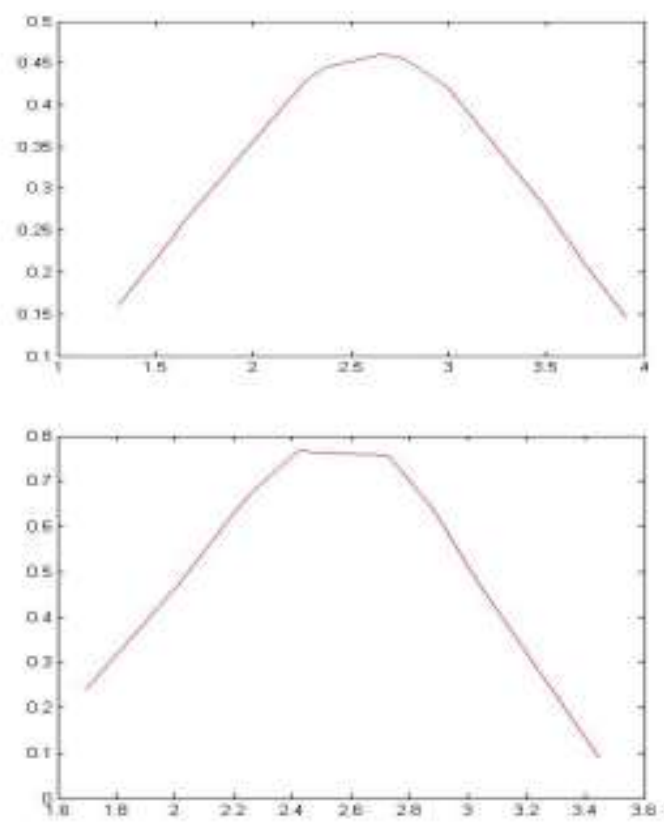

Gambar 2. Distribusi frekuensi weibull tahun 2016 dan tahun 2017 
Gambar 2 memperlihatkan grafik weibull kecepatan angin Kecamatan Pangarengan tahun 2016 dan tahun 2017. Berdasarkan analisa distribusi weibull didapatkan tahun 2016 kecepatan angin maksimum yaitu $2,6 \mathrm{~m} / \mathrm{s}$ probabilitas $45 \%$ sedangkan untuk tahun 2017 kecepatan angin maksimum sama seperti tahun 2016 yaitu 2,6 $\mathrm{m} / \mathrm{s}$ namun probablitasnya lebih tinggi yaitu $70 \%$.

Adapun data tekanan udara dan suhu bulanan kecepatan Pangarengan pada tahun 2016 dan 2017 terlihat pada Gambar 3 dan Gambar 4. Tekanan dan suhu rata rata bulan yang bervariasi juga menjadi salahsatu penyebab perbedaan nilai $\mathrm{k}$ dan $\mathrm{c}$ dari distribusi weibull. Berdasarkan perhitungan daya maka didapatkan potensi energi angin di wilayah kecamatan Pangarengan dalam satu tahun didapatkan berkisar pada $300-700$ $\mathrm{KWH} / \mathrm{m}^{2} /$ tahun atau sekitar $0.24-1.2$ $\mathrm{KWH} / \mathrm{m} 2 /$ hari.

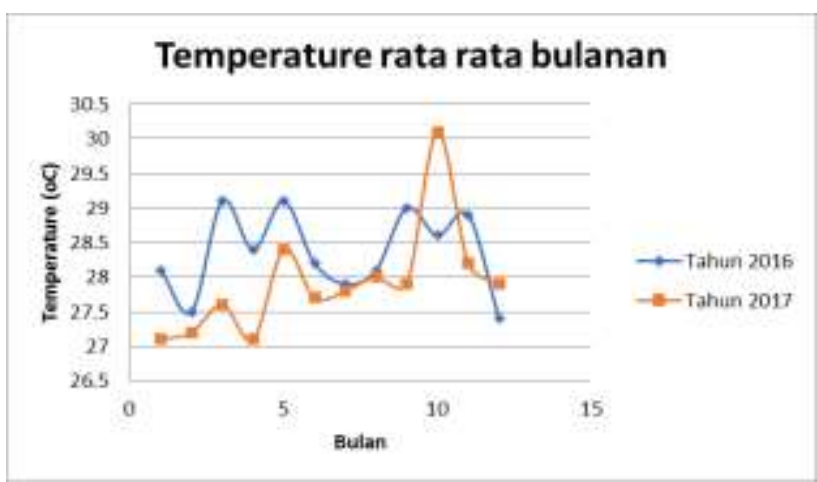

Gambar 3. Suhu rata-rata bulanan

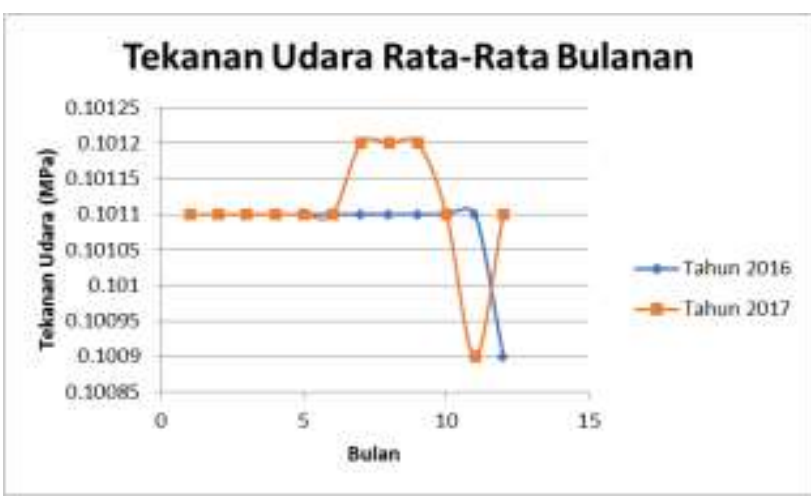

Gambar 4. Tekanan udara rata-rata bulanan

\section{KESIMPULAN}

Berdasarkan penelitian yang telah dilakukan didapatkan kesimpulan yaitu kecepatan angin rata-rata Kecamatan Pangarengan tahun 2016-2017 yaitu berturutturut yaitu $2,44 \mathrm{~m} / \mathrm{s}$ dan $2,62 \mathrm{~m} / \mathrm{s}$ dan berdasarkan analisis weibull persentase probabilitas energi angin paling banyak pada tahun 2016 yaitu 2,5 m/s sebanyak 45\% sedangkan tahun 2017 sebesar 2,6 m/s dengan probabilitas $70 \%$. Perhitungan potensi energi angin di wilayah kecamatan Pangarengan dalam satu tahun didapatkan berkisar pada $300-700 \mathrm{KWH} / \mathrm{m}^{2} /$ tahun.

\section{PENGHARGAAN}

Terimakasih disampaikan kepada KEMENSRISTEKDIKTI yang telah mendanai kegiatan ini melalui hibah Penelitian Dosen Pemula (PDP) tahun anggaran 2018. Terimakasih juga disampaikan untuk kepala BMKG Kalianget Kabupaten Sumenep.

\section{DAFTAR PUSTAKA}

[1] Arif, M., \& Hardianto, T. (2015). Aplikasi Energi Terbarukan Melalui Pengukuran Potensi Angin dengan Metode Analisis Weibull pada Pantai Puger Jember. Elektronik Jurnal Arus Elektro Indonesia (eJAEI). Retrieved from jurnal.unej.ac.id/index.php/EJAEI/article/view/1455

[2] Arota, A. S., Kolibu, H. S., \& Lumi, B. M. (2013). Perancangan Sistem Pembangkit Listrik Hibrida (Energi Angin Dan Matahari) Menggunakan Hybrid Optimization Model For Electric Renewables (HOMER). Jurnal MIPA UNSRAT, 2(2), 145-150. 
[3] Habibie, M. N., Sasmito, A., \& Kurniawan, R. (2008). Study Of Wind Energy Potency In Sulawesi And Maluku". Jurnal Meteorologi Dan Geofisika, 12(2), 181-187.

[4] Parmaputra, W., A, M. M., Destiyani, P., Husni, M. F., \& Hardianto, T. (2013). Potensi Tenaga Angin Dengan Metode Weibull Analisis untuk Penerapan Renewable Energy di Pantai Watu Ulo Kabupaten Jember. In Seminar Nasional Energi 3 (SINERGI) (Vol. 3).

[5] Ramadhan, A. I., Diniardi, E., \& Mukti, S. H. (2016). Analisis Desain Sistem Pembangkit Listrik Tenaga Surya Kapasitas 50 WP. TEKNIK, 37(2), 5963.http://doi.org/10.14710/teknik.v37n 2.9011

[6] Samas, P., Isman, F. R., Rahmatika, A. R., P, B. C. S., Rahmadi, A., Putranto,G. E., \& Isnanto, R. R. (2015). Potensi Pengembangan Pembangkit Listrik. Artikel Ilmiah - Universitas Diponegoro, 13. Retrieved from http://ejournals1.undip.ac.id/index.php

[7] Wibawa, A., Santosa, B., Mulyatno, I. P., Diponegoro, U., \& Alternatif, E. (2014). Pemanfaatan tenaga angin dan surya sebagai alat pembangkit listrik pada bagan perahu 1). KAPAL, 11(3), 108116.

[8] Yusibani, E., Fisika, J., \& Matematika, F. (2016). Analisa Kecepatan Angin Menggunakan Distribusi Weibull di Kawasan Blang Bintang Aceh Besar Wind Speed Analysis using Weibull Distribution in the Region Blang Bintang Aceh Besar. Journal of Aceh Society (JAcPS), 5(2), 7-13. 